\title{
Chewing activities and particle size of rumen digesta and feces of precision-fed dairy heifers fed different forage levels with increasing levels of distillers grains
}

\author{
F. X. Suarez-Mena, ${ }^{*}$ G. J. Lascano,† and A. J. Heinrichs ${ }^{* 1}$ \\ *Department of Animal Science, Pennsylvania State University, University Park 16802 \\ †Department of Dairy Science, California Polytechnic State University, San Luis Obispo 93407
}

\begin{abstract}
The objective of this study was to determine the effects of 2 differing forage to concentrate ratios $(\mathrm{F}: \mathrm{C})$ and various levels of corn dry distillers grain with solubles (DDGS) replacing canola meal in precision-fed dairy heifer rations on chewing behavior, rumen $\mathrm{pH}$ and fill, and particle size of rumen contents and feces. A split plot design with $\mathrm{F}: \mathrm{C}$ as whole plot and DDGS inclusion level as subplot was administered in a 4 -period $4 \times 4$ Latin square. Eight rumen-cannulated Holstein heifers $(12.5 \pm 0.5$ mo of age and $344 \pm 15 \mathrm{~kg}$ of body weight, respectively) housed in individual stalls were allocated to $\mathrm{F}: \mathrm{C}$ 50:50 (low forage) or 75:25 [high forage (HF); dry matter basis] and to a sequence of DDGS level (0, 7,14 , and 21\%; dry matter basis). Forage was a mix of $50 \%$ corn silage and $50 \%$ grass hay (dry matter basis). Diets were fed once daily and formulated to provide equal amounts of nutrients and body weight gain. No differences were found for rumen $\mathrm{pH}$ between dietary treatments. Time spent eating tended to be longer for $\mathrm{HF}$ and was not affected by DDGS inclusion rate. Ruminating time did not differ by $\mathrm{F}: \mathrm{C}$, but linearly increased as DDGS increased (422 to $450 \pm 21 \mathrm{~min} / \mathrm{d}$ ). Total chewing time tended to be longer for HF and to increase linearly as DDGS increased (553 to $579 \pm 33 \mathrm{~min} / \mathrm{d}$ ). Wet rumen digesta weight and volume were greater for HF. Geometric mean particle length of rumen contents was greater for HF $2 \mathrm{~h}$ prefeeding when analyzed with solubles (particles $<0.15 \mathrm{~mm}$ ). Proportion of rumen solubles decreased as DDGS increased $5 \mathrm{~h}$ postfeeding. Fecal geometric mean particle length and proportion of particles $>1.18 \mathrm{~mm}$ increased with increasing levels of DDGS and did not change with F:C. Total chewing time increased by the addition of DDGS and higher F:C. Heifers can compensate for lower physically effective neutral detergent fiber by modifying their chewing behavior. Rumen $\mathrm{pH}$ was never at a level that could
\end{abstract}

Received September 13, 2012.

Accepted May 2, 2013.

${ }^{1}$ Corresponding author: ajh@psu.edu induce acidosis, and lower eating time at lower F:C was somewhat compensated by time spent ruminating per unit of physically effective neutral detergent fiber intake. Dry distillers grains with solubles, when used in dairy heifer rations as a replacement for canola meal, yielded similar rumen digestion traits.

Key words: heifer, chewing, distillers grain, feeding behavior

\section{INTRODUCTION}

Feed represents the largest cost associated with raising heifer replacements (Gabler et al., 2000); thus, controlling feed costs is essential to farm profitability. One strategy to reduce feed cost yet control ADG is to limit intake of nutrient-dense rations. Restricting intake of rations with higher proportions of by-product feeds can allow for optimum growth of replacement heifers without affecting future performance (Zanton and Heinrichs, 2009b). The limit-feeding strategy has given rise to some animal well-being concerns for heifers reared under this management scheme. Redbo and Nordblad (1997) observed that limit feeding induces development and increases frequency of oral stereotypies in heifers. In cattle, stereotypies may be triggered by frustrated feed manipulation (Redbo, 1992); heifers spent less time eating and ruminating when limit-fed (Redbo and Nordblad, 1997). Broom (1983) considered occurrence of prolonged stereotypies to be indicators of poor animal well-being.

Dairy cows spend 4 to $7 \mathrm{~h} / \mathrm{d}$ eating and 5 to $9 \mathrm{~h} / \mathrm{d}$ ruminating (Beauchemin, 1991), but heifers have been reported to spend as little as 1.2 (Kitts et al., 2011) and as long as $8.5 \mathrm{~h} / \mathrm{d}$ eating (Jaster and Murphy, 1983). Thus, these activities in younger cattle have a wider range than in adult cattle depending on diet. Many factors affect these behaviors as observed in lactating dairy cows, among them: level of feed intake, ration composition, forage quality and length, and feeding method (Beauchemin, 1991).

The relationship between high-concentrate diets and rumen acidosis is well established in lactating dairy 
cows (Nocek, 1997), but results in growing heifers fed high-concentrate diets at restricted intake, where average and lowest $\mathrm{pH}$ did not reach critical levels (Moody et al., 2007; Robles et al., 2007), suggest that growing heifers can better tolerate low-fiber diets. The primary objective of this study was to determine the effects of forage to concentrate ratio $(\mathbf{F}: \mathbf{C})$ in precision-fed heifer rations on chewing activities, rumen $\mathrm{pH}$ and fill, and particle size of rumen digesta and feces as possible indicators of animal well-being. An additional objective was to determine effects of DDGS level on these parameters when substituting DDGS for canola meal while maintaining similar computed levels of protein solubility and degradability. Precision feeding in this study will be discussed as the practice of providing the animal with the exact amount of nutrients to grow at a targeted gain, as opposed to ad libitum intake.

\section{MATERIALS AND METHODS}

\section{Animals and Feeding}

All procedures involving the use of animals were approved by the Pennsylvania State University Institutional Animal Care and Use Committee. Eight Holstein heifers were surgically prepared with a rumen cannula (7.62 cm i.d.; Bar Diamond, Parma, ID) under local anesthesia 2 mo before beginning the experiment and later refitted with larger cannulas $(10.16 \mathrm{~cm}$ i.d.; Bar Diamond). Heifers (12.5 $\pm 0.5 \mathrm{mo}$ of age and $344 \pm$ $15 \mathrm{~kg}$ of BW, respectively, at the beginning of the experiment) were randomly assigned to a split-plot $4 \times$ 4 Latin square experimental design. Whole plot was an F:C of either 50:50 (low forage; LF) or 75:25 (high forage; HF) on a DM basis, and subplot was level of inclusion of DDGS, either $0,7,14$, or $21 \%$ DM basis. Forage was a mix of $50 \%$ corn silage (CS) and $50 \%$ orchard grass hay (Dactylis glomerata L.) on a DM basis. Experimental periods were $19 \mathrm{~d}$ in length with $14 \mathrm{~d}$ for adaptation and $5 \mathrm{~d}$ for sampling. Heifers were housed in individual tiestalls $(117 \times 302 \mathrm{~cm})$ with rubber mat flooring in a mechanically ventilated barn with continuous access to fresh water. Lighting was provided for $13.5 \mathrm{~h} / \mathrm{d}$, except on intensive sampling days when light was provided for $24 \mathrm{~h}$. During nonsampling days, heifers were let out in an outdoor exercise lot for 3 to $4 \mathrm{~h} / \mathrm{d}$ before feeding; BW was recorded on their way in and out of the exercise lot. Rations were balanced to provide equal amounts of nutrients and targeted to allow for $0.8 \mathrm{~kg}$ of ADG. Amount of feed offered was adjusted weekly based on actual BW; except the week before and during sampling. Single batches of grain ingredients were stored to provide for the length of the experiment. Concentrates and a mineral-vitamin pre- mix were mixed for each treatment at the beginning of each experimental period in a drum mixer (Calan Super Data Ranger, American Calan, Northwood, NH); forages were mixed daily using the same equipment. Forage mix, grain mix, and NPN source of each ration were hand mixed (because amounts were too low for mixer) and delivered once daily at $1200 \mathrm{~h}$.

\section{Samples and Analyses}

The concentrate mix for each diet was sampled at the beginning and end of each experimental period, and composited by diet at the end of the experiment. Forage mix was sampled daily during collection days. Feeds were analyzed for particle size determination as stipulated by the American Society of Agricultural and Biological Engineers (ASABE, 2007).

Feces and urine were completely collected from d 14 immediately after feeding to d 18 immediately before feeding for $4 \mathrm{~d}$ of total collection. Feces was collected hourly from vinyl-covered boards on the floor and stored in airtight containers. Every $24 \mathrm{~h}$, feces was weighed, mixed, sampled, and stored at $4^{\circ} \mathrm{C}$ until the last day of that collection period, then composited by period proportionally to daily output, and stored at $-20^{\circ} \mathrm{C}$. Urine separation from feces was accomplished using a noninvasive urinary device as described by Lascano et al. (2010).

Rumen contents were collected from dorsal, ventral, cranial, caudal, and medial areas of the rumen at -2 , $-1,0,1,2,4,6,8,10,12,16,20$, and $24 \mathrm{~h}$ after feeding on d 17 of each period. Rumen contents were mixed thoroughly, sampled, and samples were strained through 2 layers of cheesecloth; fluid was immediately analyzed for $\mathrm{pH}$ using a hand-held $\mathrm{pH}$ meter (HI 98121, Hanna Instruments, Woonsocket, RI). Whole reticulo-rumen evacuations were done at -2 and $5 \mathrm{~h}$ postfeeding at the end of each period to determine digesta weight and volume. Digesta was mixed thoroughly and a sample was stored at $-20^{\circ} \mathrm{C}$ for later analysis.

Frozen fecal and rumen digesta samples were thawed and analyzed for particle size by wet sieving using a control sieve shaker (Retsch AS 200, Haan, Germany) as described by Maulfair et al. (2011). The fraction that passed through the 0.15 -mm screen was considered soluble. Data were analyzed considering percentage of $\mathrm{DM}$ of each particle fraction retained on screens $\geq 0.15$ $\mathrm{mm}$ (retained) and including the soluble fraction (total). Physically effective NDF (peNDF) of diets was determined by multiplying diet NDF concentration by the proportion of particles retained on the 1.18-mm screen (Mertens, 1997), although the ASABE particle separator (ASABE, 2007) was used. Proportion of particles retained on the $1.18-\mathrm{mm}$ screen for each ration 
was obtained by addition of the forage and grain fractions, which were sieved separately.

Forage mix and feces were dried in a forced-air oven at $65^{\circ} \mathrm{C}$ for $48 \mathrm{~h}$ and ground through a $1-\mathrm{mm}$ screen (Wiley mill, Arthur H. Thomas, Philadelphia, PA). After drying and grinding, forage was composited by period. Fecal, grain mix, and forage mix composite samples were analyzed for DM, ash, ether extract, and CP (AOAC, 1990), as well as NDF and ADF (Van Soest et al., 1991). Fecal samples remained frozen until thawed and analyzed for CP to avoid N losses. Feed samples were reground to pass through a $0.5-\mathrm{mm}$ screen, and analyzed for starch content as described by Zanton and Heinrichs (2009a). Degradable protein was analyzed as described by Krishnamoorthy et al. (1982).

Chewing behavior was visually monitored for $48 \mathrm{~h}$ at 5-min intervals, each activity was assumed to persist for the entire 5 -min interval. The 5 categories recorded were eating, ruminating, idle, licking, and other. Oral stereotypies (tongue-rolling, biting, chain-chewing, and licking) and self-grooming were recorded as licking. Total chewing was calculated by adding eating and ruminating behaviors.

\section{Statistical Analysis}

All statistical analyses were conducted in SAS (Version 9.2, SAS Institute Inc., Cary, NC) using the MIXED procedure. Data were analyzed as a split-plot, Latin square design with fixed effects of period, forage, DDGS level, and forage by DDGS level interaction, and a random effect of heifer within forage. Because of unequally spaced rumen sampling, mean $\mathrm{pH}$ was determined by calculating the area under the response curve according to the trapezoidal rule (Shipley and Clark, 1972). Linear and quadratic contrasts of DDGS level were tested using the CONTRASTS statement. Sequences of forage and DDGS level were balanced for carryover with respect to previous forage and DDGS level such that all treatments followed every other treatment once; therefore, fixed effect of previous treatment was included in the analysis. Fixed effect of time and its interaction with other fixed effects was included in the model when multiple observations occurred in a dayexcept for chewing activities, where only daily averages were analyzed. Compound symmetry covariance structure was selected for repeated measures using goodness of fit criteria. Variance homogeneity was evaluated for main effects of forage and DDGS level and time relative to feeding when repeated measures were analyzed; evidence of significant heterogeneity was determined using the Levene test for equality of variance. Least squares means are presented in tables and evidence for statistical significance was declared at $P<0.05$.

\section{RESULTS AND DISCUSSION}

Diet ingredients and nutrient analysis are shown in Table 1, particle size in Table 2. Total DMI (Table 3) was not influenced by $\mathrm{F}$ :C, likely because the amount of feed offered was adjusted to actual BW, which varied among heifers and changed over time, increasing the error for this variable. However, when DMI was analyzed per unit of BW, DMI for HF was greater $(P<0.01)$, as nutrient density of these rations was lower than LF diets. Intake observations are part of the experimental design, as diets were fed at a lower level than ad libitum intake; consequently, no orts remained. Geometric mean particle length $\left(\mathbf{X}_{\mathbf{g m}}\right)$ and peNDF of HF were greater because of the higher proportion of forage in these diets; however, this amount did not limit DMI by exceeding gut fill, as evidenced by the lack of orts throughout the study. Fat concentration in the diet increased with the addition of DDGS, and, as a consequence, so did ME concentration; therefore, to maintain equal ME intake, diet DMI was decreased as more DDGS were added.

\section{Effects on $\mathrm{pH}$}

The data show that $\mathrm{pH}$ was not affected by $\mathrm{F}: \mathrm{C}$ or DDGS level (Table 3). Variation of $\mathrm{pH}$ during the day for LF and HF (Figure 1) suggests that heifers were not at risk of ruminal acidosis. Whereas the relationship between high concentrate diets, ruminal acidosis, and lameness is well established in lactating dairy cows, reports in growing heifers precision-fed high-concentrate diets suggest that they are not at risk of acidosis. Lascano and Heinrichs (2009) evaluated 3 levels of F:C (either 80,60, or $40 \%$ forage) fed at a restricted intake to growing dairy heifers and observed similar mean, minimum, and maximum ruminal $\mathrm{pH}$. Leupp et al. (2009) observed that $\mathrm{pH}$ increased linearly as DDGS increased, and suggested it was due to a decrease in starch concentration as DDGS increased. Rumen $\mathrm{pH}$ resilience of heifers limit-fed high-concentrate diets may be due to lower intake in comparison to ad libitum feeding systems (Lascano and Heinrichs, 2009) and increased ruminating time per $\mathrm{kg}$ of DMI.

\section{Digesta Weight and Volume and Particle Size of Digesta and Feces}

Weight and volume of rumen digesta (Table 3) were greater for HF and were not affected by DDGS level. Lower mass and volume of rumen digesta for lower F:C is similar to previous results (Moody et al., 2007; Lascano and Heinrichs, 2009). Moody et al. (2007) attributed this observation to greater DMI and reduced DM in situ digestibility of HF rations. In a review by Jung 
Table 1. Ingredient and chemical composition of low- (LF) or high-forage (HF) dairy heifer diets containing $0,7,14$, or $21 \%$ dry distillers grains with solubles (DDGS)

\begin{tabular}{|c|c|c|c|c|c|c|c|c|}
\hline \multirow[b]{2}{*}{ Item } & \multicolumn{4}{|c|}{$\mathrm{LF}$} & \multicolumn{4}{|c|}{$\mathrm{HF}$} \\
\hline & $0 \%$ & $7 \%$ & $14 \%$ & $21 \%$ & $0 \%$ & $7 \%$ & $14 \%$ & $21 \%$ \\
\hline Grass hay & 25.00 & 25.00 & 25.00 & 25.00 & 37.50 & 37.50 & 37.50 & 37.50 \\
\hline Corn silage & 25.00 & 25.00 & 25.00 & 25.00 & 37.50 & 37.50 & 37.50 & 37.50 \\
\hline $\operatorname{DDGS}^{1}$ & 0.00 & 7.00 & 14.00 & 21.00 & 0.00 & 7.00 & 14.00 & 21.00 \\
\hline Ground corn & 18.55 & 17.91 & 17.24 & 16.58 & 2.55 & 1.81 & 1.05 & 0.29 \\
\hline Mineral-vitamin $\operatorname{mix}^{3}$ & 3.00 & 3.00 & 3.00 & 3.00 & 3.00 & 3.00 & 3.00 & 3.00 \\
\hline Optigen $^{4}$ & - & 0.25 & 0.50 & 0.75 & - & 0.24 & 0.48 & 0.72 \\
\hline \multicolumn{9}{|l|}{ Chemical composition } \\
\hline $\mathrm{DM}$ & 69.38 & 69.28 & 68.93 & 68.48 & 59.33 & 59.11 & 58.49 & 57.76 \\
\hline $\mathrm{CP}, \%$ of $\mathrm{DM}$ & 15.31 & 14.59 & 15.02 & 15.12 & 13.96 & 13.90 & 14.15 & 14.19 \\
\hline RDP, $\%$ of $\mathrm{CP}$ & 43.59 & 43.78 & 45.15 & 45.32 & 54.47 & 55.28 & 52.63 & 54.77 \\
\hline $\mathrm{ADF}, \%$ of $\mathrm{DM}$ & 26.17 & 26.82 & 26.02 & 25.23 & 29.33 & 28.88 & 28.93 & 28.23 \\
\hline
\end{tabular}

${ }^{1}$ Contained $88.1 \%$ DM, $31.4 \% \mathrm{NDF}, 12.9 \% \mathrm{ADF}, 29.1 \% \mathrm{CP}$, and $11.8 \%$ ether extract on DM basis, and $16 \%$ of CP was soluble protein.

${ }^{2}$ Contained $89.1 \%$ DM, $27.9 \%$ NDF, $21.1 \%$ ADF, $40.5 \%$ CP, and $4.2 \%$ ether extract on DM basis, and $26.4 \%$ of CP was soluble protein

${ }^{3}$ Contained $3.9 \%$ vitamin E, $0.59 \%$ vitamin ADE, $48.5 \%$ distillers corn with soluble vitamin D, $10.0 \%$ plain salt, $29.4 \%$ limestone, $4.6 \%$ magnesium oxide, $1.3 \%$ trace mineral premix, and $1.6 \%$ selenium premix.

${ }^{4}$ Optigen is a NPN source (256\% CP, DM basis) from Alltech, Inc. (Lexington, KY).

${ }^{5}$ Ether extract.

${ }^{6}$ Estimated: $\mathrm{ME}=\mathrm{TDN} \times 0.04409 \times 0.82$.

and Allen (1995) it was determined that rumen passage rate can be reduced by increasing forage fiber in the diet, because of its lower digestibility and the increase of ration particle size. This suggests that heifers on HF that had greater peNDF (Table 1) would have a slower rate of passage. In the present study, rumen contents weight and volume data changed at a similar rate from $5 \mathrm{~h}$ postfeeding to $2 \mathrm{~h}$ prefeeding for $\mathrm{HF}$ and $\mathrm{LF}$ and the soluble fraction difference of rumen digesta between $\mathrm{HF}$ and LF remained constant at both time points. Thus, the difference in rumen weight and volume is likely an effect of greater intake for HF, and the greater forage proportion in the ration that retains water.

\section{Chewing Activities}

Time spent eating tended to be longer for HF than LF $(P=0.09$; Table 4$)$; and this was expected as DMI was greater for HF. Similar observations were reported by Kitts et al. (2011) who added straw (to constitute about $30 \%$ of feed) to a TMR ( $40 \%$ forage) fed at lower than ad libitum intake. Kitts et al. (2011) observed that time spent eating increased from $72 \mathrm{~min} / \mathrm{d}$ (heifers fed TMR only) to 204 and $288 \mathrm{~min} / \mathrm{d}$ for heifers fed straw on the side or in the TMR, respectively. Also, addition of straw increased eating time of ad libitum-fed prepubescent heifers, from $180 \mathrm{~min} / \mathrm{d}$ when fed a 69:31 F:C

Table 2. Particle size of forage $\operatorname{mix}^{1}$ and low- (LF) or high-forage (HF) dairy heifer diets






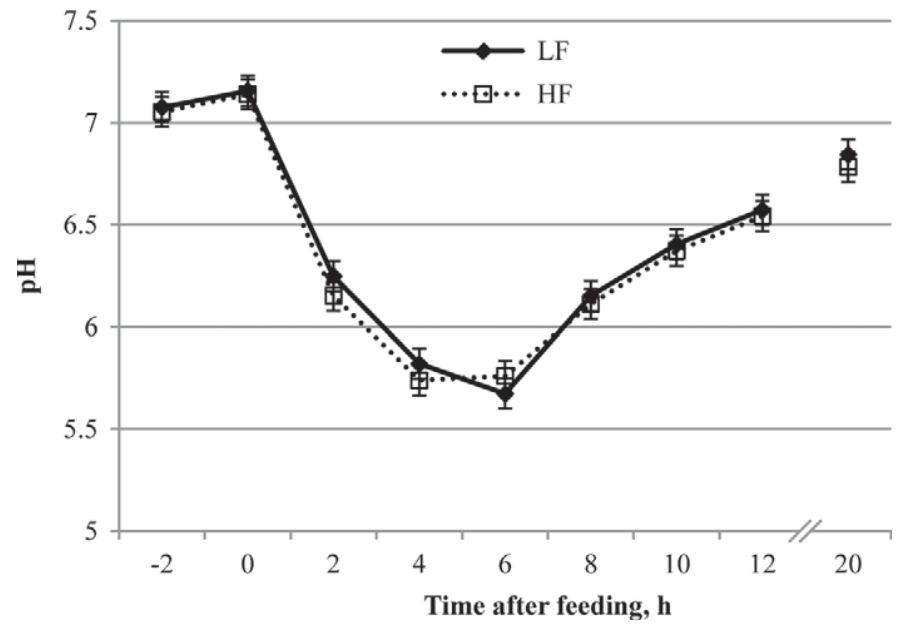

Figure 1. Mean rumen $\mathrm{pH}$ variation after feeding in heifers fed low- (LF) or high-forage (HF). $P>0.7$ for forage $\times$ time interaction.

TMR to $198 \mathrm{~min} / \mathrm{d}$ when straw (20\% of DM) was added to the TMR (Greter et al., 2008). Feeding method also affected time spent eating for heifers offered grass hay ad libitum with a fixed amount of concentrate (about 62:38 F:C); when feed was offered separately (with grain top dressed) or as a TMR, heifers spent 138, 168, and $186 \mathrm{~min} / \mathrm{d}$ eating (DeVries and von Keyserlingk, 2009).
Greater eating times have been reported for heifers with ad libitum access to hay and not supplemented with concentrates; Jaster and Murphy (1983) fed alfalfa hay as the only feed source to Holstein heifers and observed an average of $510 \mathrm{~min} / \mathrm{d}$ eating. These data confirm the generally accepted theory that dairy cattle spend progressively more time eating as $\mathrm{F}: \mathrm{C}$ or quantity of slowly digestible or indigestible feed intake increases (Beauchemin, 1991). Although feeding method was not part of the scope in the present study, it should be considered, as it also affects time spent eating. Short eating times of heifers in the present study and limitfed heifers in Kitts et al. (2011) may be in part because animals fed a restricted DMI typically increase eating rate (g/min; Church, 1988). In Hoffman et al. (2007), when ad libitum intake of gravid Holstein heifers was compared with $80 \%$ of ad libitum DMI, time spent eating decreased by $48 \%$ in heifers fed restricted amounts. This supports the previous statement that limit-fed heifers eat at a greater rate; limit-fed heifers used $52 \%$ of the time to eat $80 \%$ of the amount of feed compared with ad libitum-fed heifers. In the present study, heifers in $\mathrm{HF}$ and LF treatments had similar $\mathrm{min} / \mathrm{kg}$ of DMI eating (Table 4) despite diet differences. Thus, eating time in precision-fed heifers may be a behavioral response to feed restriction. Time spent eating and min/

Table 3. Intake, BW, and rumen digesta weight and volume and $\mathrm{pH}$ of dairy heifers fed low- (LF) or high-forage (HF) diets containing $0,7,14$, or $21 \%$ dry distillers grains with solubles (DDGS) at $2 \mathrm{~h}$ pre- and $5 \mathrm{~h}$ postfeeding ${ }^{1}$

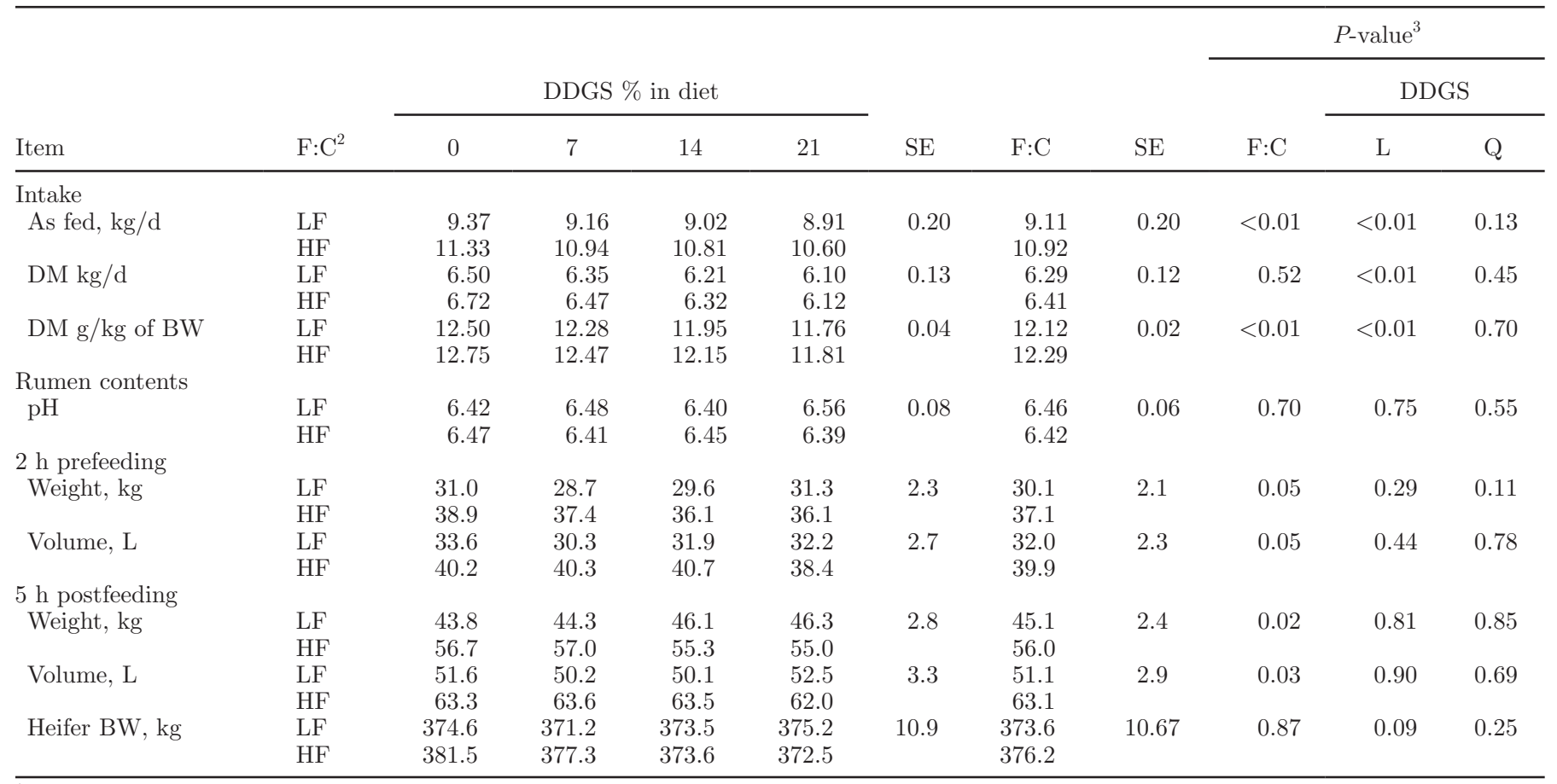

${ }^{1}$ Time effect for weight and volume, $P<0.01$.

${ }^{2}$ Forage to concentrate ratio.

${ }^{3} \mathrm{~L}=$ linear; $\mathrm{Q}=$ quadratic. 
Table 4. Chewing activities of dairy heifers fed low- (LF) or high-forage (HF) diets containing $0,7,14$, or $21 \%$ dry distillers grains with solubles (DDGS)

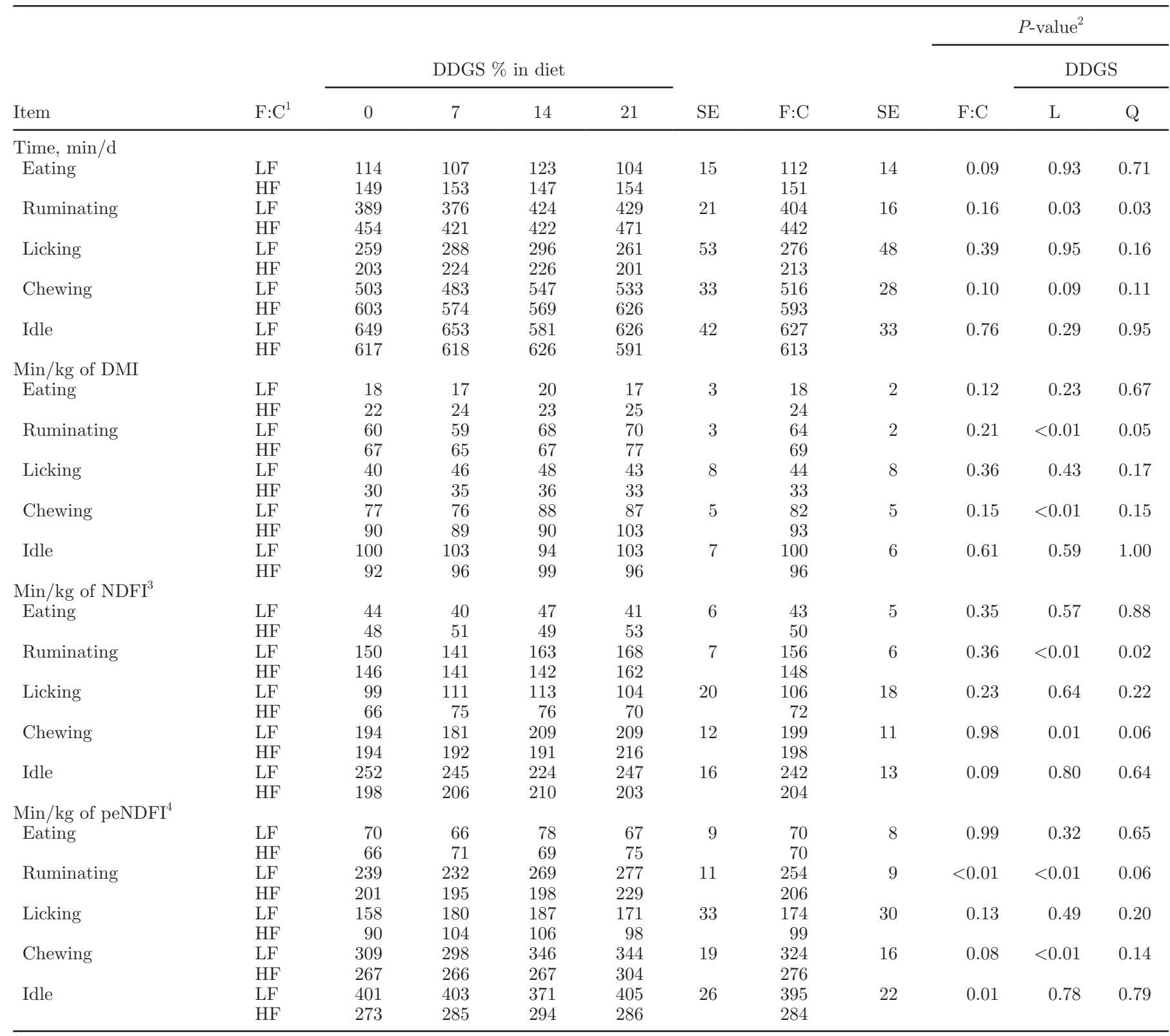

${ }^{1}$ Forage to concentrate ratio.

${ }^{2} \mathrm{~L}=$ linear; $\mathrm{Q}=$ quadratic.

${ }^{3}$ Nondetergent fiber intake.

${ }^{4}$ Physically effective NDF intake $=$ proportion of particles $>1.18 \mathrm{~mm}$ determined by ASABE particle separator multiplied by NDF concentration of feed.

$\mathrm{kg}$ of DMI and NDF intake (NDFI) were not affected by DDGS inclusion, and $\mathrm{min} / \mathrm{kg}$ of NDFI was similar at these levels of $\mathrm{F}$ :C.

Daily rumination time (Table 4) was not influenced by F:C; this differs from Zebeli et al. (2007), who observed that rumination time increased for rations higher in F:C fed to late-lactating dairy cows. Interestingly, late-lactating cows in Zebeli et al. (2007) spent between
242 and $405 \mathrm{~min} / \mathrm{d}$ ruminating, less than heifers in the present study that spent between 376 and $471 \mathrm{~min} / \mathrm{d}$ ruminating. This is in spite of the DMI of those cows being twice the DMI of heifers (Zebeli et al., 2007). Consequently, ruminating $\mathrm{min} / \mathrm{kg}$ of DMI and $\mathrm{min} / \mathrm{kg}$ of NDFI of heifers were greater, suggesting that shorter eating times of precision-fed heifers are in part compensated for by lowering rumination rate; however actual 
rumination rate was not determined. When considering peNDF in the present study, heifers in LF spent 48 more $\mathrm{min} / \mathrm{kg}$ of physically effective NDFI (peNDFI) ruminating than HF-fed heifers, which suggests that heifers compensate for reduced peNDF in the ration by prolonging time spent chewing each bolus. A similar compensatory behavior was described by Metz (1975), who observed more rumination time per kilogram of intake as intake decreased in limit-fed, nonpregnant, nonlactating cows fed long hay. However, when those cows were fed hay wafers, rumination time increased linearly as DMI increased. Ruminating time per unit of DMI and NDFI was not affected by F:C in the present study, whereas Zebeli et al. (2007) observed higher ruminating $\mathrm{min} / \mathrm{kg}$ of DMI for increased forage but similar min/kg of NDFI.

Despite NDF being similar across DDGS level (Table 1), within $\mathrm{F}: \mathrm{C}$ daily ruminating time and ruminating $\mathrm{min} / \mathrm{kg}$ of DMI, NDFI, and peNDFI (Table 4) linearly increased as DDGS level raised $(P<0.01)$. When DDGS replaced other concentrates in lactating cow diets to about $10 \%$ of diet DM, ruminating time and ruminating $\mathrm{min} / \mathrm{kg}$ of DMI were not affected, a reduction in ruminating $\mathrm{min} / \mathrm{kg}$ of NDFI was observed, and time spent lying increased by nearly $2 \mathrm{~h} / \mathrm{d}$ (Penner et al., 2009). We speculate that, in the present study, the increase in ruminating time and ruminating time per unit of DMI, NDFI, and peNDFI as DDGS increased in the diet may be due to changes in the rumen microbial population related to FA content increasing in the diet as DDGS level increased. It may also be due in part to changes in the synchrony of rumen protein and carbohydrate availability with the different diets, as canola was decreased as DDGS increased. Our attempt was to balance diets to minimize these differences with the use of a NPN source.

Total chewing time (eating plus ruminating; Table 4) tended to be longer for HF in this study, similar to the pattern for eating time. Yet, the tendency was only for a $15 \%$ change, whereas the tendency for eating time of $\mathrm{HF}$ was $35 \%$ longer, and ruminating time was only slightly longer for $\mathrm{HF}$ and not statistically different. Also, chewing minutes per kilogram of peNDFI tended to be shorter for HF. Together, these suggest that LF heifers somewhat compensated for less time spent eating and less peNDF in the ration by longer chewing time per unit of peNDFI. As in the present study, Zebeli et al. (2007) observed that chewing time decreased at lower F:C; this was also seen in steers fed different amounts and sources of concentrates (Sudweeks, 1977). As a result of longer ruminating time as DDGS increased, total chewing time of heifers in this study showed a similar pattern.
Daily time spent licking of LF (Table 4) was 30\% more than that of HF, but not statistically different. In this study, licking as self-grooming was not differentiated from oral stereotypies, and times reported may be inflated because each observation was assumed to last 5 min. Kononoff et al. (2002) compared the observational method used in this study with an automatic system and determined that the observational method overestimates daily eating and ruminating times by 3.6 and $10.3 \%$, respectively. Licking time was not compared in the Kononoff et al. (2002) study, but because licking is a more scattered activity and has shorter bouts, it might be overestimated to a greater degree by the observational method. Nevertheless, these values are valid as frequency observations, though this limits the conclusions we can obtain from the data because a frequency increase does not necessarily mean an insult to the animal's well-being. More research that quantifies time and not only incidence of stereotypic behavior for limit-fed heifers at various F:C is necessary to determine if forage level affects animal well-being.

Kitts et al. (2011) suggested that limit-fed heifers could be at greater risk of lameness because of long inactive standing time and risk of subacute ruminal acidosis. In their study, heifers fed the ration with lower F:C (more restricted) spent more time standing inactively; this observation is in agreement with Hoffman et al. (2007). However, heifers in the Kitts et al. (2011) study spent the same total time standing (inactive standing plus standing while eating). Although greater time standing does increase risk of laminitis in lactating cows (Nocek, 1997; Cook et al., 2004), growing heifers may not be affected by it or may be affected to a lesser extent if total standing time is similar. Also, it can be speculated that out of reach feed in adjacent pens may be part of the reason why heifers stood inactively.

Retained $\mathrm{X}_{\mathrm{gm}}$ of rumen digesta (Table 5) was not affected by $\mathrm{F}: \mathrm{C}$, but total $\mathrm{X}_{\mathrm{gm}}$ was greater for $\mathrm{HF} 2$ $\mathrm{h}$ prefeeding, consistent with numerically greater total $\mathrm{X}_{\mathrm{gm}} 5 \mathrm{~h}$ postfeeding. These differences are compensated by a tendency of LF to have a greater proportion of the soluble fraction at both time points. Proportion of particles $>1.18 \mathrm{~mm}$ was lower $2 \mathrm{~h}$ prefeeding for both treatments than $5 \mathrm{~h}$ postfeeding. Level of DDGS had no effect on $\mathrm{X}_{\mathrm{gm}}$ and percentage of particles $>1.18 \mathrm{~mm}$ of rumen digesta.

Fecal $\mathrm{X}_{\mathrm{gm}}$ and percentage of particles $>1.18 \mathrm{~mm}$ (Table 6) did not change with F:C. Small differences were observed in the distribution of retained particles. The 3.35-mm screen had a tendency, and the 0.6-mm screen had a greater proportion of retained particles for LF. This was compensated by the numerically greater proportion retained on the $0.15-\mathrm{mm}$ screen for HF; these 
Table 5. Particle size of rumen digesta of dairy heifers fed low- (LF) or high-forage (HF) diets containing 0, 7, 14, or 21\% dry distillers grains with solubles (DDGS) at 2 h preand $5 \mathrm{~h}$ postfeeding

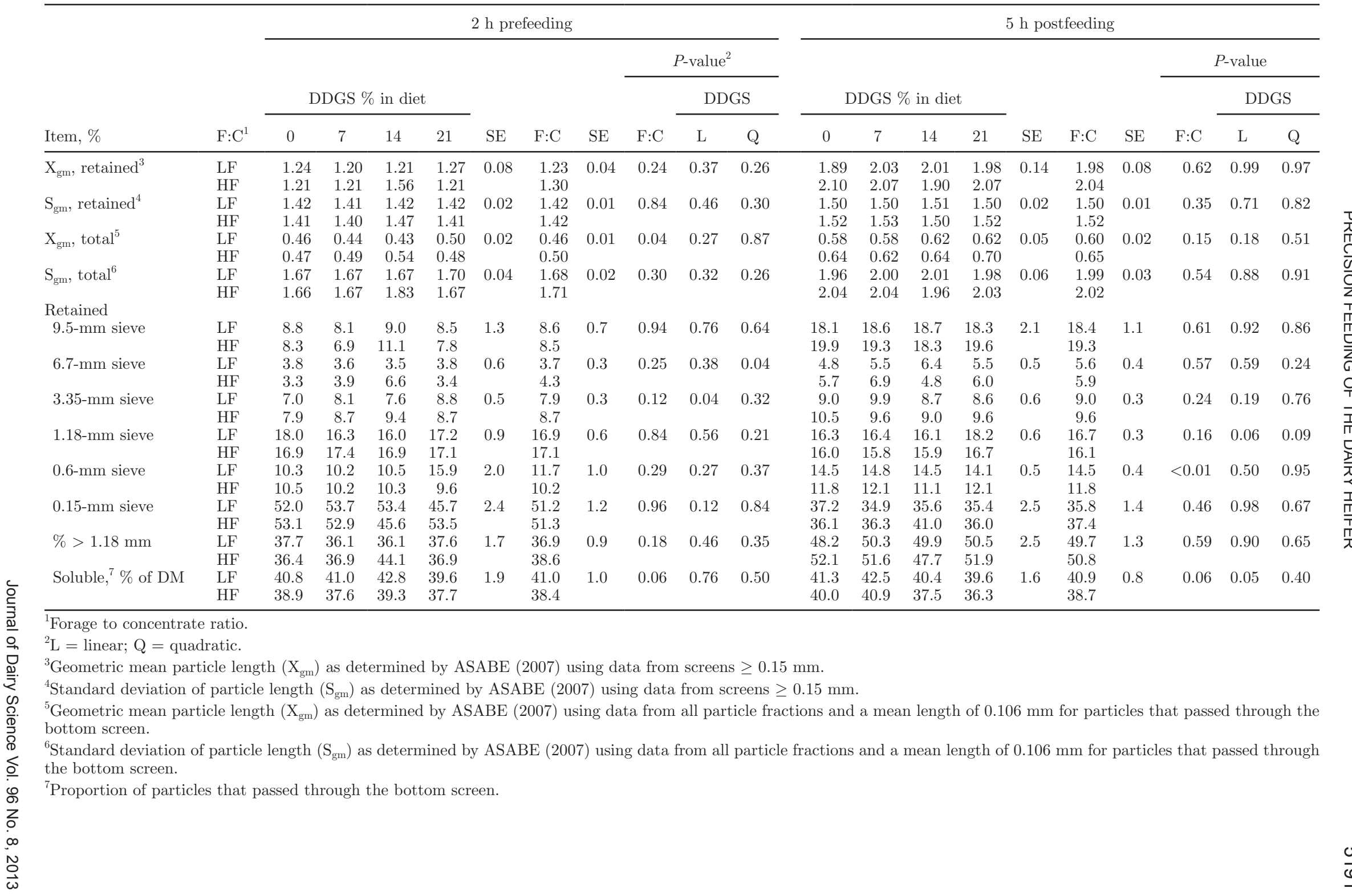


differences disappeared when the soluble fraction was included in the analysis (data not shown), which, along with small differences, also make these effects of little physiological importance. Nevertheless, it is interesting that for $\mathrm{F}$ : C the differences are shown in the $3.35-\mathrm{mm}$ and not the 1.18-mm sieve. Maulfair et al. (2011) suggested that the critical particle size for rumen escape in high producing dairy cows is about $4 \mathrm{~mm}$.

The $\mathrm{X}_{\mathrm{gm}}$ and percentage of particles $>1.18 \mathrm{~mm}$ in feces increased with increasing levels of DDGS. This was a consequence of a similar effect on the proportion of particles on 1.18- and 3.35-mm screens, the opposite effect was observed for the $0.15-\mathrm{mm}$ screen, and no effect was observed for the $0.6-\mathrm{mm}$ screen. This effect could be a response to decreased digestibility as DDGS increased. Fat concentration in the diet increased as more DDGS were added, and high fat intake can adversely affect rumen fermentation and reduce fiber digestion (Church, 1988); however, levels added in this study and the type of fat should not have been deleterious to rumen function.
Retained $\mathrm{X}_{\mathrm{gm}}$ of fecal particles observed in this study was $55 \%$ of the amounts observed in lactating cows by Kononoff and Heinrichs (2003) and Maulfair et al. (2011). This difference is reduced when analyzed with solubles; total $\mathrm{X}_{\mathrm{gm}}$ of the present study was $81 \%$ of that reported by Maulfair et al. (2011). The retained percentage of particles $>1.18 \mathrm{~mm}$ was much greater in lactating cows than in the present study; 48 and $37 \%$ in Kononoff and Heinrichs (2003) and Maulfair et al. (2011), respectively. This is likely because of greater intake and faster rate of passage in lactating cows, because total percentage of particles $>1.18 \mathrm{~mm}$ in the present study was similar to that observed in steers fed ad libitum dry forage by Poppi et al. (1985). Small differences in fecal particle size, in spite of greater $\mathrm{F}: \mathrm{C}$, may be related to greater ruminating time of $\mathrm{HF}$. Greater fecal particle length as DDGS level increased suggests that less rumen fiber degradation occurred, because particle length was similar across DDGS level within F:C (data not shown), and chewing time increased as DDGS level increased.

Table 6. Fecal particle size of dairy heifers fed low- (LF) or high-forage (HF) diets containing 0, 7, 14, or 21\% dry distillers grains with solubles (DDGS)

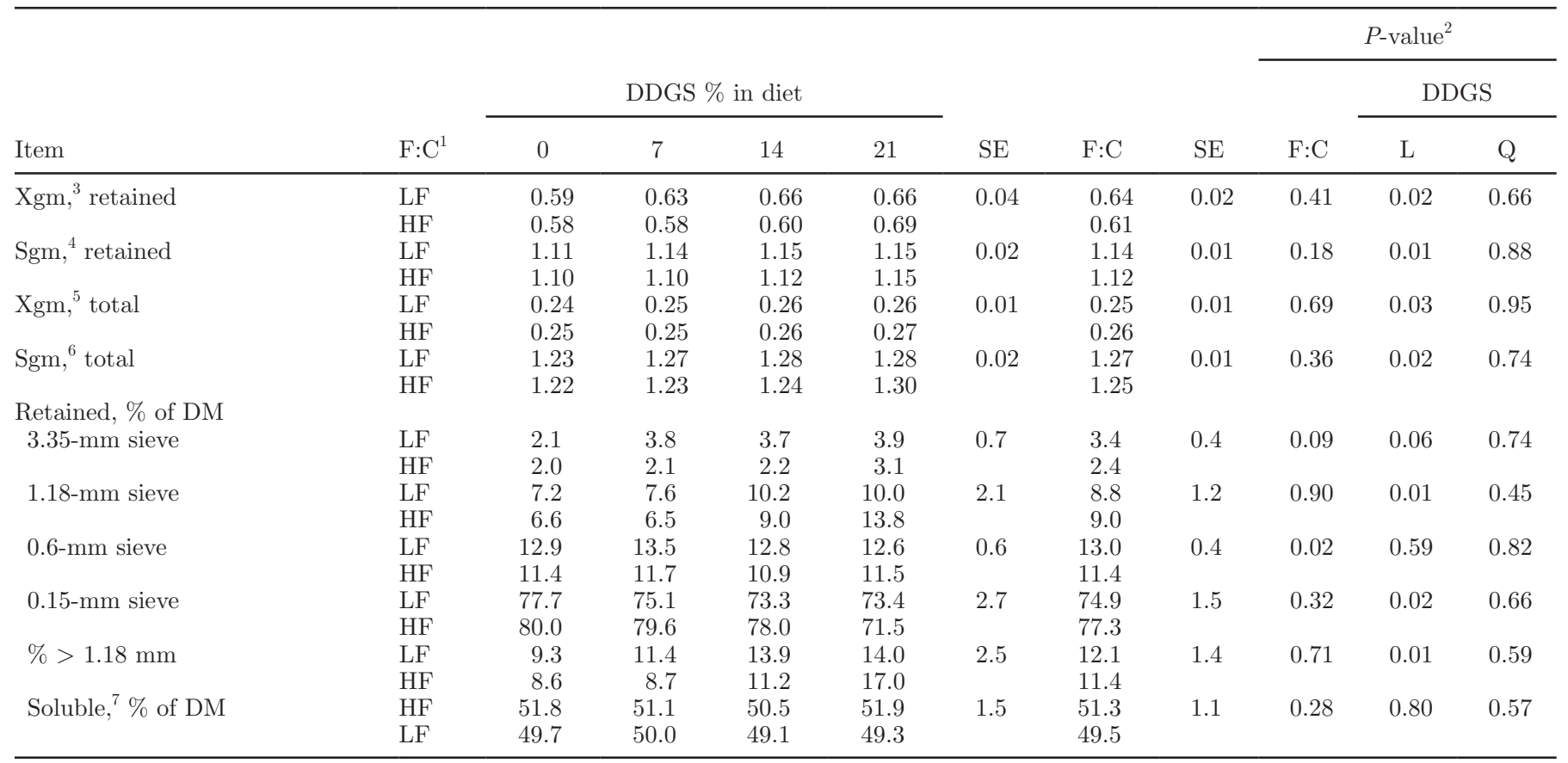

${ }^{1}$ Forage to concentrate ratio.

${ }^{2} \mathrm{~L}=$ linear; $\mathrm{Q}=$ quadratic.

${ }^{3}$ Geometric mean particle length $\left(\mathrm{X}_{\mathrm{gm}}\right)$ as determined by ASABE (2007) using data from screens $\geq 0.15 \mathrm{~mm}$.

${ }^{4}$ Standard deviation of particle length $\left(\mathrm{S}_{\mathrm{gm}}\right)$ as determined by ASABE (2007) using data from screens $\geq 0.15 \mathrm{~mm}$.

${ }^{5}$ Geometric mean particle length $\left(\mathrm{X}_{\mathrm{gm}}\right)$ as determined by ASABE (2007) using data from all particle fractions and a mean length of 0.106 mm for particles that passed through the bottom screen.

${ }^{6}$ Standard deviation of particle length $\left(\mathrm{S}_{\mathrm{gm}}\right)$ as determined by ASABE (2007) using data from all particle fractions and a mean length of 0.106 $\mathrm{mm}$ for particles that passed through the bottom screen.

${ }^{7}$ Proportion of particles that passed through the bottom screen. 


\section{CONCLUSIONS}

Time spent eating increases at higher $\mathrm{F}$ : $\mathrm{C}$ in precisionfed heifer rations, which is somewhat compensated by an increase in time spent ruminating per unit of peNDFI at lower $\mathrm{F}$ : $\mathrm{C}$, reducing the gap in total time spent chewing. In spite of similar NDF content, ruminating time increased with increasing level of DDGS replacing canola, which consequently increased chewing time. Small differences in rumen digesta and fecal particle size, in spite of large diet $\mathrm{F}: \mathrm{C}$ differences, further support the conclusion that heifers compensate for lower $\mathrm{F}$ : $\mathrm{C}$ by modifying chewing behavior. Rumen $\mathrm{pH}$ did not change by $\mathrm{F}$ :C or DDGS level replacing canola and was likely not at a level that could induce acidosis. Canola meal can be replaced by DDGS in heifer diets with no apparent effects on measured rumen parameters. No evidence of compromised animal well-being was observed due to the feeding strategy and diets used in this study.

\section{ACKNOWLEDGMENTS}

Sincere appreciation is extended to Coleen Jones of the Pennsylvania State University for editorial support.

\section{REFERENCES}

AOAC. 1990. Official Methods of Analysis. 15th ed. Association of Official Analytical Chemists, Arlington, VA.

ASABE (American Society of Agricultural and Biological Engineers). 2007. Method of determining and expressing particle size of chopped forage materials by screening. ANSI/ASAE. S424. 1:663665. ASABE, St. Joseph, MI.

Beauchemin, K. A. 1991. Ingestion and mastication of feed by dairy cattle. Vet. Clin. North Am. Food Anim. Pract. 7:439-463.

Broom, D. M. 1983. Sterotypies as animal welfare indicators. Pages 81-87 in Indicators Relevant to Farm Animal Welfare. Curr. Top. Vet. Med. Anim. Sci. Vol. 23. D. Smidt, ed. Martinus Nijhoff, The Hague, the Netherlands.

Church, D. C. 1988. The Ruminant Animal Digestive Physiology and Nutrition. 1st ed. Prentice Hall, Englewood Cliffs, NJ.

Cook, N. B., T. B. Bennett, and K. V. Nordlund. 2004. Effect of free stall surface on daily activity patterns in dairy cows with relevance to lameness prevalence. J. Dairy Sci. 87:2912-2922.

DeVries, T. J., and M. A. G. von Keyserlingk. 2009. Short communication: Feeding method affects the feeding behavior of growing dairy heifers. J. Dairy Sci. 92:1161-1168.

Gabler, M. T., P. R. Tozer, and A. J. Heinrichs. 2000. Development of a cost analysis spreadsheet for calculating the costs to raise a replacement dairy heifer. J. Dairy Sci. 83:1104-1109.

Greter, A. M., T. J. DeVries, and M. A. G. von Keyserlingk. 2008. Nutrient intake and feeding behavior of growing dairy heifers: Effects of dietary dilution. J. Dairy Sci. 91:2786-2795.

Hoffman, P. C., C. R. Simson, and M. Wattiaux. 2007. Limit feeding of gravid Holstein heifers: Effect on growth, manure nutrient excretion, and subsequent early lactation performance. J. Dairy Sci. 90:946-954.

Jaster, E. H., and M. R. Murphy. 1983. Effects of varying particle size of forage on digestion and chewing behavior of dairy heifers. J. Dairy Sci. 66:802-810.

Jung, H. G., and M. S. Allen. 1995. Characteristics of plant cell walls affecting intake and digestibility of forages by ruminants. J. Anim. Sci. $73: 2774-2790$

Kitts, B. L., I. J. H. Duncan, B. W. McBride, and T. J. DeVries. 2011. Effect of the provision of a low-nutritive feedstuff on the behavior of dairy heifers limit fed a high-concentrate ration. J. Dairy Sci. 94:940-950.

Kononoff, P. J., and A. J. Heinrichs. 2003. The effect of corn silage particle size and cottonseed hulls on cows in early lactation. J. Dairy Sci. 86:2438-2451.

Kononoff, P. J., H. A. Lehman, and A. J. Heinrichs. 2002. Technical note: A comparison of methods used to measure eating and ruminating activity in confined dairy cattle. J. Dairy Sci. 85:18011803.

Krishnamoorthy, U., T. V. Muscato, C. J. Sniffen, and P. J. Van Soest. 1982. Nitrogen fractions in selected feedstuffs. J. Dairy Sci. $65: 217-225$.

Lascano, G. J., and A. J. Heinrichs. 2009. Rumen fermentation pattern of dairy heifers fed restricted amounts of low, medium, and high concentrate diets without and with yeast culture. Livest. Sci. 124:48-57.

Lascano, G. J., G. I. Zanton, A. J. Heinrichs, and W. P. Weiss. 2010. Technical note: A noninvasive urine collection device for female cattle: Modification of the urine cup collection method. J. Dairy Sci. 93:2691-2694.

Leupp, J. L., G. P. Lardy, K. K. Karges, M. L. Gibson, and J. S. Caton. 2009. Effects of increasing level of corn distillers dried grains with solubles on intake, digestion, and ruminal fermentation in steers fed seventy percent concentrate diets. J. Anim. Sci. 87:2906-2912.

Maulfair, D. D., M. Fustini, and A. J. Heinrichs. 2011. Effect of varying total mixed ration particle size on rumen digesta and fecal particle size and digestibility in lactating dairy cows. J. Dairy Sci. 94:3527-3536.

Mertens, D. R. 1997. Creating a system for meeting the fiber requirements of dairy cows. J. Dairy Sci. 80:1463-1481.

Metz, J. H. M. 1975. Time patterns of feeding and rumination in domestic cattle. PhD Thesis. Mededelingen Landbouwhogeschool, Wageningen Univ., Wageningen, the Netherlands.

Moody, M. L., G. I. Zanton, J. M. Daubert, and A. J. Heinrichs. 2007. Nutrient utilization of differing forage-to-concentrate ratios by growing Holstein heifers. J. Dairy Sci. 90:5580-5586.

Nocek, J. E. 1997. Bovine acidosis: Implications on laminitis. J. Dairy Sci. 80:1005-1028.

Penner, G. B., P. Yu, and D. A. Christensen. 2009. Effect of replacing forage or concentrate with wet or dry distillers' grains on the productivity and chewing activity of dairy cattle. Anim. Feed Sci. Technol. 153:1-10.

Poppi, D. P., R. E. Hendricksen, and D. J. Minson. 1985. The relative resistance to escape of leaf and stem particles from the rumen of cattle and sheep. J. Agric. Sci. 105:9-14.

Redbo, I. 1992. The influence of restraint on the occurrence of oral stereotypies in dairy cows. Appl. Anim. Behav. Sci. 35:115-123.

Redbo, I., and A. Nordblad. 1997. Stereotypies in heifers are affected by feeding regime. Appl. Anim. Behav. Sci. 53:193-202.

Robles, V., L. A. González, A. Ferret, X. Manteca, and S. Calsamiglia. 2007. Effects of feeding frequency on intake, ruminal fermentation, and feeding behavior in heifers fed high-concentrate diets. J. Anim. Sci. 85:2538-2547.

Shipley, R. A., and R. E. Clark. 1972. Tracer methods for in vivo kinetics. Academic Press, New York, NY.

Sudweeks, E. M. 1977. Chewing time, rumen fermentation and their relationship in steers as affected by diet composition. J. Anim. Sci. 44:694-701.

Van Soest, P. J., J. B. Robertson, and B. A. Lewis. 1991. Methods for dietary fiber, neutral detergent fiber, and nonstarch polysaccharides in relation to animal nutrition. J. Dairy Sci. 74:3583-3597.

Zanton, G. I., and A. J. Heinrichs. 2009a. Digestion and nitrogen utilization in dairy heifers limit-fed a low or high forage ration at four levels of nitrogen intake. J. Dairy Sci. 92:2078-2094.

Zanton, G. I., and A. J. Heinrichs. 2009b. Review: Limit-feeding with altered forage-to-concentrate levels in dairy heifer diets. Prof. Anim. Sci. 25:393-403.

Zebeli, Q., M. Tafaj, I. Weber, J. Dijkstra, H. Steingass, and W. Drochner. 2007. Effects of varying dietary forage particle size in two concentrate levels on chewing activity, ruminal mat characteristics, and passage in dairy cows. J. Dairy Sci. 90:1929-1942. 